\title{
LANGUAGE AND DISCOURSE IN NIGERIAN EDUCATION: HISTORIC IMPLICATION OF GENDER ISSUES
}

\author{
EKWUTOSI ESSIEN OFFIONG ${ }^{1}$ \\ ${ }^{1}$ University of Calabar, Department of History and International Studies, Etagbor, PMB 1115, Calabar \\ 2018, Nigeria. ORCID:0000-0002-9913-7300,Email: ekwutosioffiong@gmail.com
}

ABSTRACT: This paper examines the influence and power of language in education in Nigeria from the pre-colonial to colonial and post-colonial times. This is with regards to the effect of language on gender issues within the country. Nigeria, a country on the west coast of Africa is multi-ethnic with over 150 (one hundred and fifty) ethnic groups with their different indigenous languages and cultures. As a colony of the British, the Christian missionaries who first introduced western form of education in Nigeria used the British English language as a medium of communication and subsequently with the establishment of colonial administration in the country, English language was made the official language of the country. This paper contains a critical analysis of the use of English Language in the country and its implications on communication in social and economic interactions of individuals within the various communities across the country. It argues that the proliferation of the English language was through education of which the male gender benefitted more than their female counterparts due to the patriarchal dominance in the country. The data for the study was collated from random interviews and other written sources. The research discovered that the knowledge and ability to speak fluently and write the English language had a direct influence on the socio-political and economic status of individuals within the country. The women who benefitted from this were comparatively fewer than the men due to some prevailing conditions of what could be called in the present the subjugation of women the society. Critical discourse analysis is adopted for this study. It argues that English language dependency by Nigerians shows that forms of the colonial experience is still evident, and these were all initiated during the past interac- 
tions with west through the transatlantic slave trade and colonial rule. This is because discourse as a social construct is created and perpetuated by the persons who have the language power and means of communication. The Nigerian family being of a conservative orientation derives its power directly from the father who is the patriarch of the family as obtained in the traditional set up of communities and the Nigerian society in general. This has grave effect on the opposite gender

KEYWORDS: English Language, Power, Education, Gender, Communication, Discourse

\section{INTRODUCTION}

The goal of this research is to examine the relevance of language and discourse in Nigerian education and its historic implication of gender issues. Using the historical descriptive analysis method of interrogation, the paper will be based on desk analysis of some relevant discourses on the subject matter and a small collection of random interviews conducted by the researcher during interactions with women in various groups across the country. The objectives of the study include, an analysis of the historical background and features of education in the different periods of Nigerian education, the relevance of the knowledge of language in order to participate actively and contribute to social discourse within the society and mention will be made of the challenges the females encounter in their participation in this social discourse.

\section{METHODS}

\section{Analytical approach-critical discourse analysis}

This research uses the historical descriptive analysis method of interrogation adopting the critical discourse studies in which languages plays a powerful role in reproducing and transforming power relations along many different dimensions (of class, culture, gender, sexuality, disability and age etc) and is sanctioned. It also asserts that 'Discourse transmits and produces power, it reinforces it, but also undermines and exposes it, renders it fragile and makes it possible to thwart' (Foucault 1998: 100).

Language and discourse in education are powerful instruments through which a society or individuals can be controlled. The individuals that possess the knowledge determine the exclusion and inclusion of others. Foucault explains that 'we must make allowance for the complex and unstable powers whereby discourse can be both an instrument and an effect of power (Foucault 1978: 101).

The historian is interested to know what happened or was that happening, what was it that was happening the time events or processes occurred in the past under study, the historian further 'aims to characterize, evaluate, to explain... and therefore in the last analysis narrate actions performed in the recorded past'. (Pocock 2018) 'The historian, then, maybe thought of as scrutinizing the actions and activity... and asking questions about what it has been and done, answers to which will necessarily take the form of narrative, of actions and their consequences. (Pocock 2018) This research 
method of the historian is what is adopted in this paper.

\section{DATA AND PROCEDURE}

The paper is based on desk analysis of some relevant discourses on the subject matter. Two books and three articles make up the primary data for the study. African women; sentenced by tradition by N. M. Majekwu Chikezie, (2011). Gender mainstreamism in Nigeria's political development; from hindsight to foresight by S.A Effah-Attoe, 2018, the Historical Legacy of Gender Inequality in Nigeria by E. B. Ikpe, Educational Policy in Nigeria from the Colonial Era to the post-independence period by Hauwa Imam (2012), and soft power language in social inclusion and exclusion and the unintended research outcome by A. Odrowaz-Coates 2018. The reference to the social and political conditions within the society that influenced language and education in Nigeria during our period of study were analysed and documented as it relates to the topic of this paper.

Language as a tool for communication within any community is useful and necessary for information, expression and issuance of directives. The language in use at any point in time; spoken or written must be comprehensible to the sender and the receiver of the message for effective communication to take place. In Nigeria there are over two hundred (200) indigenous languages. The tree major ones are Hausa, Igbo and Yoruba while the official language of the country is English. This enables socio-economic and political interactions amongst both nationals and non-nationals. The knowledge and competence to speak and write English Language within various communities "enabled individuals to gain self-confidence and community pride, enhancing their language skills and communicative skills in both languages” (Odrowaz- Coates 2018, cf. Cosaro 2018). This made such persons to be considered as literate and educated in Nigeria. The knowledge of English Language over the years has equipped individuals with linguistic skills superior to their counterparts and made them to command more power, aided their empowerment and made them to be perceived as more competent in some spheres of life. Thereby strengthening their positions in their various communities (Odrowaz-Coates 2018, Cosaro 2018). Also being able to communicate effectively in the English language offers considerable advantages (Odrowaz-Coates 2018).

Nigeria is a country on the west coast of Africa. The country is made up of about Two hundred and fifty (250) ethnic groups with their different languages and cultural heritage. The largest of these ethnic groups are Hausa/Fulani, Igbo and Yoruba. (Nig @ 50, 2010). With the subjugation and subsequent colonization of the country in the late $19^{\text {th }}$ century and early $20^{\text {th }}$ century, the country came under the colonial rule of the British. English language was therefore adopted as the language of communication for all official matters. Before the establishment of colonial rule, the Christian missionaries had already introduced the use of English language as a medium of teaching and instruction in schools and for preaching in churches. English language thus became a requirement for communication and socialisation with the new institutions within the communities namely - the schools, churches, European trading agencies and government parastatals. The knowledge of this language determined ones' social inclusion or exclusion' (Odrowaz-Coates 2018). Several years after independence, Nigeria as a 
country is still using the English language as primary mode of communication. This 'reveals the influence of one political entity on another without military power but through economic and cultural influence' (Odrowaz-Coates 2018) Nigeria being a predominantly patriarchal society experienced the situation where mostly the males who were the initial beneficiaries of the activities of these institutions( schools, churches and government agencies) within the society gained more and several advantages over their female counterparts as a result of several social and cultural practices thereby perpetuating the gender issues within the family and society. Also, within the country, power distribution in the family is highly conservative and conventional referring to the man, wife/wives and child/children.

Gender 'may be defined as a socially constructed feminine or masculine identity of an individual enforced through socialisation process which becomes a basis of social division and a set of every day social practices (Idyorough 2005, Odrowaz-Coates 2015). The process of socialisation involves ones inclusion or exclusion and the knowledge of the mutually intelligible language determines this. Therefore, in gender relations within families or the community people without the requisite knowledge are usually secluded while those that possess the knowledge are included. There are several definitions of education using a basic one, education is defined as "the art of making available to each generation the organised knowledge of the past' (Good 1959). Within the Nigerian society the males were the bulk of first group of knowledgeable ones (educated or literate) when formal education was introduced, while the females lacked the knowledge and were considered (illiterate and uneducated). The scenario has not changed much particularly among the rural community dwellers.

Michel Foucault's discourse theory has been a veritable tool on which educational debates, social policies and academics have focused and this is the theory that shall be adopted for the analysis of this topic. In the social contexts, discourse theory is concerned with issues of power and domination. It illustrates a tendency within critical conditions to focus on knowledge as a material element in social life (Popkewitz 1977). For Foucault, (1977) It is through discourse (through knowledge) that we are created; and that discourse joins power and knowledge, and its power follows from our casual acceptance of the reality with which we are presented .' Discourse being a social construct is said to be created by individuals who possess the power and means of communication. According to (Weedon 1977) Discourse transmits and produces power, it can undermine it, expose it, make it fragile and can thwart it. Foucault (1972) explains that discourses are about what can be said and thought and about who can speak when and by what authority, Discourses can be in written and oral form and are discernible in the social practices of everyday life within the society (Weedon 1977) Foucault observed that language plays a vital role in the reproduction and transformation of power relations in many dimensions (of class, culture, gender, sexuality, disability, age and others) and is sanctioned. Thus, the language, thoughts and desires of individuals within any given community are regulated and managed through discourse.

In considering language and discourse in Nigerian education, the concepts of discourse, power, culture and language are said to be dialectically interrelated with each complementing the other. None is more powerful than the other, each one equally 
shapes the other (Foucault 1977). Corson (1995) sees language as an instrument of power and a useful tool for deconstructing power discourse. Bourdiew (1977) observes that language is not only an instrument of communication or knowledge, it is also an instrument of power. In Nigeria, western formal education with English language as the medium of communication was initially controlled by the missionaries, followed by the colonial government and now the Nigerian government. Thereby, the official discourses of the Christian missions and the state in respect of educational policies (namely core curriculum, modes of assessment and school management) are obvious instances through which discourse and language became instruments of power. In the larger society the men possessed this power aided by these institutions and the traditions and cultures of the communities.

In this paper, language and discourse in Nigerian education and its historic implication of gender issues will be analysed during the following periods: Pre Colonial period, Missionary and Colonial period and Post-Colonial period.

\section{PRE-COLONIAL PERIOD}

The language and education of people in pre-colonial Nigeria was varied amongst the various ethnic groups across the country. In the pre-colonial period, the territory today called Nigeria was made up of highly influential and diverse communities North, South, East and West. These include the North Eastern kingdom of Kanem Borno, the Hausa kingdoms of Kano, Katsina, Zaria, Gorbir and others. And in the $19^{\text {th }}$ century the Sokoto Caliphate. In the North Central there were the Tivs, Idoma, Igalla, Jukuns and others. The Yoruba kingdoms are in south western Nigeria and there are the Kingdom of Benin in the mid-west, the Igbo communities of the East and several other communities in the south eastern part now known as the South-South geo political region.(Obaro:1980) All these communities had their different languages and traditional forms of education and practices which varied from one community to the other. Educational activities usually entailed the learning of some traditional gender specific crafts and cultural instructions through initiation or puberty rites. The curricula were informal and comprised of lessons for developing the child's physical skill, character, intellectual skills and sense of belonging to the community as well as inculcating respect for elders and giving specific vocational training and the understanding and appreciation of the community's cultural heritage (Fafunwa 2014). In all the communities, the leaders (males and females) taught the younger ones individually, in groups or under a formal apprenticeship some skills and what was expected of them as adults in the society. Education was therefore the process of cultural transmission and renewal, the process whereby the adult members of a society carefully guided the development of infants and young children, initiating them into the culture of the society(Adeyemi \&Adeyinka:2002) In view of the fact that the society was predominantly patriarchal, the men made the rules and it was naturally expected that all others that is the females and children must obey these rules. Furthermore, the country can be conveniently described as possessing a conservative orientation, that is, the people "focus on binding people into groups and institutions" (Odrowaz-Coates 2019). This 
is because within the country, the three main religious inclinations namely African Traditional Religion, Christianity and Islam are very traditional in their approach to issues concerning males and females. The religious and social norms of each religion is followed to the later and in all these religions, females are subordinate to males as such anything outside of that is a misnomer and an anti-religious or anti-social behaviour which attracts repudiation.

Common features of female education among the different ethnic group included the domestically oriented teachings and the range of social and economic activities that the different communities reserved for the proper orientation and socialisation of women. This seemed to have made women in pre-colonial societies to hold a complementary position to men whereas patrilineal and patriarchal kinship structures predominated these societies. The women were taught how to care for their husbands and children that is basically the art of home management as they were expected to have or bear children particularly sons who will ensure the future of the families and communities (Mojekwu 2012). The women were also engaged in farming activities and craft making. The type of craft depended on the communities or ethnic group. This allowed the women to provide the material resources and support needed for the care of the family. On the whole the female in pre-colonial society was trained for the domestic sphere, marriage and motherhood while the males were trained for leadership, warriors, hunters and other positions of authority. The various communities determined what should be taught to each gender. It has been asserted that "societal discourse mediates its power and control through institutions and elites who are charged with saying what counts as true" (Talbani 1996). According to Foucault, each society has what it considers as truth, its "general politics of truth, that is the type of discourse it accepts and makes function as true” (Piscoe \& Letseka 2013). He considers society as a space for a struggle to establish and transmit a regime of truths, develop techniques and procedure to inculcate and transmit cultural values which are considered to be true. Thus, the leaders within any community use political, economic and social apparatuses to control and dominate (Talbani 1996). Language and discourse in pre-colonial Nigerian society was therefore mainly determined by the leaders of the various communities. They determined what should be taught to and inculcated in the males and females. This produced gender role stereotyping by which certain social roles are attributed to men and women based on the traditional gender division of labour in a particular society even when such attributes are not built on reality and are discriminatory. Gender role stereotyping supports the existing structural arrangements under the patriarchal system which are discriminatory and are in favour of men and portray such roles as "natural and normal" for women (Idyorouhg 2005).

From birth males and females are raised differently and made to experience different environments, they are led on different paths before they are able to choose their own. These paths set by their parents or other adult figures in their lives set them on certain paths (Cordier 2012) leading to a difference in personality, career choices or relationships. Thus, throughout life males and females are perceived as two different personalities and should stay on separate paths (Brescoll:2013). The silent but rigorous education into the patriarchal and matriarchal stereotypes was ingrained in the 
traditional institutions of Nigeria. Men and women grew up to know what was expected of them and accepted their gender roles as given. According to Ocitti (1971):

Pre-colonial education, even in the most centralised and stratified societies, was gender-based, with boys and girls receiving that kind of education which enabled them to fulfil social defined masculine and feminine responsibilities respectively. Male education thus produced farmers, warriors, blacksmiths, rulers and other male dominated occupations from which women were excluded. On the other hand, female education was predominantly designed to produce future wives, mothers and home makers.

\section{UNDER MISSIONARY PERIOD}

Christian missionary activities that impacted on the education and language in Nigeria began in the 1840s in Yoruba land (south west) and Efikland (south south) (Ajayi 1965, Ayandele 1966, Aye 1967). One major mode of evangelism by missionaries was through the establishment of schools. The schools were opened by the various missionary bodies who operated in the country as they considered the schools as "the nursery of the infant churches, the principal hope for the success of their work" (Ajayi 1965). The attendance in the schools established initially in some areas was encouraging and in others poor. Over the years, as the communities witnessed the result of missionary activities in the schools, attendance began to improve steadily and with time several communities within which the missionaries operated had schools. The language of instruction was English language. Attendance of school therefore brought a new status to persons in the society as those who could read and write in English language were considered as literate and others who not were termed illiterates. In most Nigerian Communities, female attendance of these formal western type schools established by the missionaries was not patronized at all. In some communities it was a taboo or considered as waste of time and family resources to educate female children who were said later would discard the family name for their husband's name. In Efikland, a prominent community leader Henry Cobham, had stated that" Book (Bible) no good for women, and women no fit saby book" (Aye 1967). This was the general view of his fellow men in the society in the 1850s. For others, education of the girl child delayed her marriage and most girls were usually withdrawn from school to marry. It was also believed that formal education affected the morality of the female child because of the claim that in the formal school system, the girls become exposed to sex and sexuality matters. Such exposure they imagined will lead to promiscuity which will rob the girls of their chastity, which was a highly valued moral quality of the girl child and her parents moral training to be rated at marriage. As a result of these and other stereotypes several women were therefore denied access to education in Nigeria. The scenario was worse in northern Nigeria where the prevalence of Islam had restricted the activities and spread of the missionaries to this region. Islamic laws governing the conduct of men and women prevailed in the north. The women across the country could therefore not be educated in this new language to be part of the new 
discourse because of the limited access to education and the training of women. The few who had the privilege of attending these early missionary schools were trained for either nursing, teaching or other domesticated disciplines (Mojekwu 2012). The missionary schools for a period of time were the only institutions of western education. The schools were however criticized for their rudimentary nature and content, the insistence on moral Christian education and Bible lessons. The schools served as institutions of modernization and learning of the English language before colonial administration. The Christian mission schools first established were used for evangelization and the training of religious indoctrinators, the education of women was less important to them as they were not clergymen nor teachers necessary for church growth except for the few who were later trained as nurses and teachers in subsequent years. The introduction of colonial administration did not alter the limitation of women in the educational institutions.

From available records, colonialism was a male dominated venture in view of the fact that all colonial officers were male. Being products of the Victorian society's family philosophy, the home was regarded as a place of refuge from the pressures of public life. The women were expected to keep the home and make it a safe place of escape for the men from the vicissitudes of public and working life while the men were to provide for the homes, protect the women from the harsh labour of the industrial era and generally from the pressures of public life. As a result of this, British women did not participate in politics, had no voting rights and could not contest election. It was by the late $19^{\text {th }}$ century and early $20^{\text {th }}$ century that women in Britain began to fight for their political rights.(Jaggar 1983, Ikpe 2004) Coming from such cultural milieu, the colonial administrators did not regard women as in anyway suitable for administrative positions in Nigeria except as producers of agricultural products. Colonial administration by the British officially introduced the English language as the lingua franca of the country Nigeria. English language was not only used in schools and churches but was the official language for all economic, social and political transactions throughout the country. This introduction further alienated individuals who were not knowledgeable in the language.

The pattern of colonial rule using the indirect rule policy did not help matters. The indirect rule policy placed emphasis on administration through or based on existing traditional political institutions. The dominance of men was therefore re-enacted, emphasized and perpetuated. Even in circumstances where new chiefs known as "Warrant Chiefs" were to be appointed, colonial officers did not consider women as capable of occupying such offices (Ikpe 2004). The introduction of western education was inadvertently used to perpetuate the inequality of genders. The males benefited more as compared to the females. The establishment of government schools did not improve the situation. Colonial education was aimed at training men for clerical jobs in the lower cadres of the colonial service and the commercial houses. Effah-Attoe (2018) opined that

during the colonial period, education was functional. School curricula reflected what the British considered functional for their needs. Thus, the curricular for 
girls enabled girls to become good housewives, rather than income earners for a living. The curricula for girls were made up of mainly subjects as needlework, domestic science and singing.

Pereira (2007) buttressing the above discussion had stated that,

the primary goal of girl's education according to the prevailing belief of the time (with respect to colonial era) was to instill correct morals and teach girls on modest behavior. (Female) education was not supposed to offer training for jobs or in the academic subjects. Colonial administrators, missionaries and Christian parents agreed that mission schools were best suited to provide such trains - until the 1930s when their perceptions changed slightly.

The neglect of female education was attributable to the government's opposition to the employment of women in the colonial civil service. This attitude was discernable when the Lagos Women's League in South western Nigeria, appealed to the colonial government for the employment of women, the then Chief Secretary replied; "It is doubtful whether the time has arrived when women could be employed generally in the clerical service in substitution for men. In future they may be employed as telephone operators, counter clerks and book binders" (Mba 1982).

Gleaned from the above, the few educated women during this period encountered challenges of employment outside their perceived "traditional" careers as teachers and nurses. The general situation was that education for girls where available emphasized character training, domestic science and marriage training. Throughout the colonial period, the proportion of girls that received any form of western education was low particularly in the rural arrears as compared to the boys. As for northern Nigeria,

British policy of indirect rule restricted the activities of the missionaries in the predominantly Muslim northern protectorate thereby, curtailing the spread of Christianity and Western education leading to a considerable educational gap between the North and the Southern part of Nigeria (Imam 2012).

Throughout this period the education of girls was comparatively low in all parts of Nigeria. According to Anya (2003) the ratio of girls to boys in the colleges was 1:35 or a 2.7 percent. The percentage is said to have dropped in the 1930 s to 2.1 percent or 559 boys to 12 girls. The situation started to change in the 1950s with more girls being educated. "However, till the end of colonial rule, female education remained the exception rather than the rule" (Ikpe 2004). The introduction of western education brought in a new principle of differentiation which led to salaried employment, prestige and access to positions of responsibility. As a result of the prestige now attached to employment, traditional parents still preferred to finance the education of their sons more than that of their daughters. Women education was still considered as a waste of money in view of the fact that they were expected to get married. Most of the early educated women ended up marrying and staying at home as housewives. This further convinced many already reluctant parents of the undesirability of educating women (cf. Ikpe 2004). This resulted in the majority of the women not being empowered to be active participants in the language and discourse of the society. In view of 
the fact that a knowledge of the language determined inclusion or exclusion, the bulk of the women folk are excluded from the discourse within the society as a result of this challenge. Even "though the situation has been changing gradually and more women are acquiring different levels of education, the majority of the women still remain illiterate vis-à-vis the men (Akpan 1996) within the country Nigeria.

The need for the knowledge of the English language in order to be able to communicate in the general public was so pervasive that there developed in the country a language known as "Pidgin English '. This is a grammatically simplified form of English which developed as a result of the contact of the indigenous people with the English language with words and sounds they could not pronounce correctly as they had no opportunity to learn it within the right environment of a school setting. The pidgin English developed from the coastal cities and has spread across the entire country. Today people who are not literate in the English language manage to communicate with others using the pidgin English though there are no written texts on it. The knowledge of the pidgin English has aided the majority of the illiterate women folk to communicate and interact within the society generally but not in official government circles where the knowledge of spoken and written English is required.

\section{POST-COLONIAL EDUCATION}

Nigeria gained political independence from British colonial rule on the $1^{\text {st }}$ of October 1960. After this date the English language has remained as the official language of the country. During the missionary and colonial education period the Bible and other literary books were translated to and written in many indigenous languages namely Efik, Hausa, Yoruba, Igbo (Ajayi 1965, Ayandele 1966, Aye 1967), and others latter. After these pioneer works, several other indigenous writers have written some literary works in some indigenous languages. In spite of all these, no texts on different subjects have been fully developed and written in any of the three major languages viz. Hausa, Igbo and Yoruba in order that such may be used for learning and instruction in schools in replacement of the English language. According to Woolman (2001)

Nigeria has in all, 270 indigenous Nigerian languages that may qualify as instructional tongues for early primary classrooms. Many of the smaller languages have no written orthography, which makes materials production quite difficult.... It is for this reason that English is still largely used, and the language was adopted as the language of instruction since independence.

The 1981 revised policy on education only prescribes that each child should be encouraged to learn one of the three major languages in the country other than their mother tongue (Federal Republic of Nigeria 1981). Education in the country is controlled by the government with the three tiers of government controlling each tier accordingly. The Local governments are in charge of primary education, the States are in charge of secondary education although the Federal government controls some secondary schools and at least one or two of such institutions are located in each state of the country across the 36 (thirty six states) and in the Federal capital territory, Abu- 
ja. The Federal government is in charge of tertiary education which includes the Universities, Polytechnics and other special institutes located is states across the country. State governments also own universities and there exist several privately-owned educational institutions (primary, secondary. Tertiary) within the country. In all these institutions from the primary to the tertiary levels, the English language is the main language of learning and instruction. In order to be eligible for admission to study any course in any Nigerian university the potential candidate must possess a minimum pass at Credit level in English language from the Senior School Certificate examination normally conducted by the West African Examination Council (WAEC) and the National Examination Council (NECO) Candidates without the requisite qualification are usually not admitted.

The education of girls continued to suffer even after independence, according to Effah-Attoe (2018)

five years after independence (from the colonialist), women participation in 'administrative governance' reflected a grim picture, as only $6.9 \%$ of wages and salaried labour force in Nigeria were women; by 1970, only $8.7 \%$ of the total number of established staff in the Federal Civil Service were women, and by 1980 the figure rose to a paltry $12.6 \%$.

The argument here is, how can women become policy makers when they struggle to make their presence felt in the administrative governance of the country, Nigeria. A situation partly birthed by traditional values, missionary and colonial education policy on the girl child, and the lack thereof, of education for female children who developed into the women of the 1960s and 1970s.

Effah-Attoe (2018) further submitted that:

By 1979 , about $72.9 \%$ of urban girls were not attending schools. And only $6 \%$ of adult were literate, according to the censor conducted by Population Reference Bureau. However, by 2008, women literacy level in Nigeria, according to UNESCO Institute of Statistical Report, October 2015, was placed at 41\%. The social attitude of Nigerians towards women is one which suggests that, women needed only to be educated to be good housewives (a trend which colonial education instituted). Thus, when financial issues arise, most parents prefer to withdraw girls rather than boys from school.

As Foucault (1972) stated that "every educational system is a means of maintaining or modifying the appropriateness of discourses with the knowledge and power they bring with them". Education can be as of right the instrument whereby individuals in the society can gain access to any kind of discourse. Thus, every education system is a political means of maintaining or of modifying the appropriation of discourse, with the knowledge and power it carries with it. The power that the English language carries in Nigeria, is what can be termed as "Soft power". Soft power according to (Nye 2004, as cited in Odrowaz-Coates 2018) is a theoretical concept established to study the influence of political entities on one another. This political concept can be applicable in the analysis of language and power where English language is as a me- 
dium of soft power. The knowledge of and possession of competent skills in English language gives individuals within the society great advantages of opportunities and further empowers them to participate in discourses thus English is the main language of communication within the country while the indigenous languages are used for private discussions and at some socio-cultural events which the locals celebrate. However, whenever such celebrations involve the invitation of persons from other ethnic groups, there is always a translation to English through an interpreter.

Parents at home particularly in the cosmopolitan and other cities within the country use the English language in communication with their children even at home. They take it for granted that their children must speak good English and they believe that their knowledge of English will have an impact on their future and the opportunities available to them (Odrowaz-Coates 2018). The soft power impact of the language is so overwhelming that the ability to speak English is said to create a soft hierarchy amongst persons in the social, economic and political spaces based on the level of knowledge (Odrowaz-Coates 2018). Generally, people are appreciated, admired and consulted as a result of their eloquence and level of articulation of the English language.

Effah-Attoe (2018) in explaining some of the problems that hindered the political development of women in Nigeria and the future prospect reiterated that:

Another problem facing women is lack of adequate education. Women constitute a larger percentage of the illiterate group in Nigeria. This could be attributed to the fact that in most families, parents prefer their sons to go to school instead of their daughters, since the later will get married and be incorporated into another family. Thus, a larger percentage of the girls remained uneducated and unexposed in Nigeria, especially prior independence.

Policy making requires sound education, especially in the area of issues being under review. With a systematic and institutionalized trend of not adequately educating the girl child on subjects that prepare them for jobs, public offices and consequently policy making, the women who emerged from such historical trend by these periods, female enrollment into schools was still very poor as Effah-Attoe (2018) submitted.

On the issue of male-female enrollment in education by level and by sex from 1960 . to 1990 . Pereira (2007) provided a tabulated statistic on the issue, which is presented and analyzed accordingly: 
Table 1. ENROLLMENT IN EDUCATION BY LEVEL OF SEX in 1960

\begin{tabular}{|c|c|c|c|}
\hline $\mathbf{1 9 6 0}$ & FEMALE & MALE & $\begin{array}{c}\text { Widening Percentage Disparity on Fe- } \\
\text { males }\end{array}$ \\
\hline $\begin{array}{c}\text { Primary } \\
\text { Education }\end{array}$ & $1,087,147(37.2 \%)$ & $1,829,471(62.8 \%)$ & $-25.6 \%$ (percentage disparity) \\
\hline $\begin{array}{c}\text { Secondary } \\
\text { Education }\end{array}$ & $28,528(21.1 \%)$ & $106,826(78.9 \%)$ & $-57.8 \%$ (an increased disparity) \\
\hline $\begin{array}{c}\text { University } \\
\text { Education }\end{array}$ & $196(7.7 \%)$ & $2,349(92.3 \%)$ & $-84.6 \%$ (an increased disparity) \\
\hline
\end{tabular}

Source: Self-generated, based on Pereira 2007.

I included the 4th column titled "Widening Percentage Disparity on Female" in the above table for the purpose of analysis. Accordingly, one can see clearly the widening disparity in male-female educational enrolment as soon as the level of education goes higher. Thus, in primary education the percentage was $-25 \%$ against females; and by secondary school level, it increased to - $57.8 \%$ against females and a ridiculous- $84.6 \%$ when it got to the university education level. NB: to obtain the above figures I simply subtracted boys against girl's percentage presented by Charmaine Pereira in the $3^{\text {rd }}$ and $4^{\text {th }}$ columns of her table. This widening gap in male-female education enrolment was a trend throughout the time frame under analysis (1960-1990). And is anchored on the wrong socio-academic phenomena wherein parents often send and stop the education of their female children mostly at "standard six" i.e. primary education. Thus, the number of female enrolment schools decreases as the level of education increases.

The statistics for 1970 to 1990 followed this worrying trend as will be discovered in the following tables:

Table 1. ENROLLMENT IN EDUCATION BY LEVEL and SEX (1970-1990)

\begin{tabular}{|c|c|c|c|}
\hline 1970 & FEMALE & MALE & $\begin{array}{l}\text { Widening Percentage Disparity on Fe- } \\
\text { males }\end{array}$ \\
\hline $\begin{array}{l}\text { Primary Edu- } \\
\text { cation }\end{array}$ & $\begin{array}{l}1,295,000 \\
(37 \%)\end{array}$ & $2,205,000$ (63\%) & $-26 \%$ (percentage disparity) \\
\hline $\begin{array}{l}\text { Secondary } \\
\text { Education }\end{array}$ & $\begin{array}{l}119,200 \\
(32.7 \%) \\
\end{array}$ & $244,800(67.3 \%)$ & $-34.6 \%$ (an increased disparity) \\
\hline $\begin{array}{l}\text { University } \\
\text { Education }\end{array}$ & $2,074(14.3 \%)$ & $12,394(85.7 \%)$ & $-71.4 \%$ (an increased disparity) \\
\hline
\end{tabular}




\begin{tabular}{|c|c|c|c|}
\hline $\mathbf{1 9 8 0}$ & FEMALE & MALE & Widening Percentage Disparity on Fe- \\
males
\end{tabular}

\begin{tabular}{|c|c|c|c|}
\hline $\mathbf{1 9 9 0}$ & FEMALE & MALE & $\begin{array}{c}\text { Widening Percentage Disparity on Fe- } \\
\text { males }\end{array}$ \\
\hline $\begin{array}{c}\text { Primary Edu- } \\
\text { cation }\end{array}$ & $\begin{array}{c}5,877,572 \\
(43.2 \%)\end{array}$ & $7,729,677(56.8 \%)$ & $-13.6 \%$ (percentage disparity) \\
\hline $\begin{array}{c}\text { Secondary } \\
\text { Education }\end{array}$ & $\begin{array}{c}1,243,669 \\
(42.8 \%)\end{array}$ & $1,664,797(57.2 \%)$ & $-14.4 \%$ (percentage disparity) \\
\hline $\begin{array}{c}\text { University } \\
\text { Education }\end{array}$ & $\begin{array}{c}48,855 \\
(27.0 \%)\end{array}$ & $132,016(72.0 \%)$ & $-45 \%$ (percentage disparity) \\
\hline
\end{tabular}

Source: Self-generated, based on Pereira 2007. [The above tables were obtained from Pereira (2007) who quoted the Longe Report of 1992]

One can see clearly that there exists a contrasting trend in the gender (male -female) disparity in education enrolment in Nigeria. Thus, while from the 1960s to 1990 there was an upward (increase) in female enrolment at all levels of education-primary, secondary and tertiary (i.e university). For instance, girl's enrollment into universities were $7.7 \%, 14.3 \%, 22 \%$ and $27.0 \%$ by $1960,1970,1980$ and 1990 respectively; and so, it was in primary and at the secondary school levels as well thus signifying a plausible increase in the number of females enroll led in universities. The contrasting and unfortunately persistent trend was that, the gender(male-female) disparity as the level in education increases, always widen between both gender in favour of the male against the girl child. A look at all the $4^{\text {th }}$ columns from 1960 to 1990 proves this fact. And like already argued in the course of this script, it is tied to the socio-academic misnomer where in parents usually prefer to further the education of male children as against females, either due to financial constraints, or the fact that "it might seem wasteful since the later would be married off" Effah-Attoe (2018).

By the last decade of $20^{\text {th }}$ Century (or just before the turn of the fourth republic of $21^{\text {st }}$ century) in Nigeria, the Nigeria University Commission (NUC) 2001 report in Pereira (2007), provided a statistical account on male - female disparity in education enrolment in the country between 1995 and 1998. Accordingly: 


\begin{tabular}{|c|c|c|c|}
\hline $\mathbf{1 9 9 5 / 9 6}$ & FEMALE & MALE & $\begin{array}{c}\text { Widening Percentage Disparity on Fe- } \\
\text { males }\end{array}$ \\
\hline $\begin{array}{c}\text { University } \\
\text { Enrolment }\end{array}$ & $78,087(30.3 \%)$ & $181,213(69.7 \%)$ & $-39 \%$ (percentage disparity) \\
\hline $\mathbf{1 9 9 7 / 9 8}$ & FEMALE & MALE & $\begin{array}{c}\text { Widening Percentage Disparity on Fe- } \\
\text { males }\end{array}$ \\
\hline $\begin{array}{c}\text { University } \\
\text { Enrolment }\end{array}$ & $89,984(33.1 \%)$ & $181,724(66.9 \%)$ & $-33 \%$ (percentage disparity) \\
\hline
\end{tabular}

Source: self-generated. Data obtained from Pereira (2007).

The above NUC report, when juxtaposed with the Longe report on education enrolment (both of which are in Pereira2007:130-132), did reveal a positive and obvious trend; that by 1960, 1970, 1980, 1990, 1996 and 1998 there was a decrease in the tertiary (i.e. university) education enrolment disparity ratio between boys and girls as follows: $-84.6 \%,-71.4 \%,-55.8 \%,-45 \%,-39 \%$ and $-33 \%$. A cursory look at the tables proves this fact.

Hopefully, currently or in the nearest future, there may be a balance in the ratio of male-female enrolment in schools across Nigeria, especially at the tertiary level of education, where the gap seems to widen when compared to secondary and primary educational levels.

The continual use of English language for all social, economic and political interactions and transactions shows that Nigeria as a country has not and cannot easily disconnect itself from its past colonial experience. The continual use of English language is a form of 'language dependency', colonialism is far from over, it has just changed the dimension and the social mask it had been using to maintain the global power relations that were initiated right from the $15^{\text {th }}$ through the $20^{\text {th }}$ centuries (Odrowaz-Coates 2017). Thus, the power of English language to maintain a leading position in Nigerian education, confirms that the term "soft power" may be used in relation to language (Odrowaz-Coates 2018). It can be asserted that the soft power influence could be a source of additional power in personal relations and the negotiation of self-positioning. This is said to be true in both private and formal relations and the cultural influence of English language on the perceived roles and rights of women increased the awareness of "gender egalitarianism and provided a notion of empowerment" (Odrowaz-Coates 2019). This awareness so created has increased agitations from women within the society. It has also empowered them to speak up on gender issues of concern which have been perpetuated through the various traditional and cultural practices within the country. The society is undergoing some changes "for not all men are successful patriarchs and not all women passive victims" (Silberschmidt 1999). However, the gap still exists remains as the country though influenced by the cultural norms brought in from abroad through the English language still has a strong conservative approach to gender issues as a result of the influence of Islam in the northern parts and Christianity and traditions in the southern states. Gender issues involving inequality and marginalization still persist and are far from being solved.

The awareness so created is prevalent in the cities and among people of a particular class. The poor urban dwellers and the rest of the rural community dwellers still 
discriminate against the females in access to education. This has left several females uneducated and without any other skills. This perpetuates a condition of inequality and the continual dependence of females on males in most relationships and in the larger society. These women can easily be manipulated because, similar to OdrowazCoates research findings: "realizing the importance of possessing English language skills, but through lack of opportunity, they are not able to linguistically catch up in order to participate, so they give up and accept the situation positioning them in a less favorable place in the social hierarchy" (Odrowaz-Coates 2019). The barriers that keep girls out of school are well known and are still prevalent in the society. According to the "US Agency for International Development and the World Bank, 57 percent of the 72 million primary school aged children who do not attend school are females, additionally, girls are four percent less likely than boys to complete primary school" (Gender Statistics 2010).

\section{CONCLUSION}

The paper has traced the historical process of the development of education in Nigeria. It has observed that educational instructions and learning had been gender specific in the pre-colonial period. The pattern and conditions did not change much during the missionary education period except that a new variable which was the English language was introduced. During the colonial era, access to and attendance of formal western educational institutions still continued to be limited and not accessible to most females particularly those in the rural communities. The gender ratio of attendance still favoured the males. The new language of instruction in schools now became the new language in the entire society and a very limited number of women possessed the knowledge of the English language.

In post-colonial Nigeria, the use of English language has been further legitimized thereby widening the gap between those with the language power and those that have not. The ratio of female attendance at school is still poor as a result of cultural and traditional practices prevalent in the society. The urban women now empowered by education and their knowledge of the English language have been making efforts at drawing the attention of the government and other agencies to these inequalities and disparities. However after obtaining the necessary qualification and language power as the case maybe, the core religious practices of the major religions within the country namely African Traditional Religion, Christianity and Islam inhibits the powers and abilities of the women to press for anything outside the norms of the various religious faiths which if for nothing else have one thing in common, the subordination of women to men in the society. This has been the scenario of the discourses on gender issues within the Nigerian society in the past years. Knowledge and language power has given the women that possess it a voice to speak out however what happens to such opinions raised by those voices with regards to implementation as it affects gender issues remains a challenge within the country. 
FUNDING: This research was funded by the UNESCO/Janusz Korczak Chair fellowship 2019 obtained through the Polish Commission for UNESCO.

CONFLICT OF INTEREST: The author declares no conflict of interest.

\section{REFERENCES}

Agayi, Ade. 1965. Christian Missionay in Nigeria 1841-1891: The Making of a new Elite. London: Longman.

Akpan, Charles, P. 1996. "Gender imbalance in Access to Education implication for development in South eastern. Nigeria.” Pp. 171-180 in Women development and the Nigerian environment, edited by Y. Oruwari. Ibadan: Vintage publishers.

Ayandele, Emmanuel. 1966. The missionary impact on modern Nigeria: A political and social Analysis. London: Longman.

Aye, Efiong. 1967. Old Calabar Through the centuries. Calabar.

Bourdieu, Pierre. 1977. Outline of a theory of practice. Cambridge: Cambridge University Press.

Bourdieu, Pierre and Jeane-Claude Paserson. 1977. Reproduction in education, society and culture. London: Sage.

Breseall, Victoria et al. 2013. "The effect of system-justifying motives on endorsement of essentialist explanations for gender differences." Journal of Personality and Social Psychology 105(6): 891-908.

Cordier, Bernard. 2012. “Gender, betwixt biology and society.” Sexologies 21(4): 192194.

Corson, David. 1995. Discourse and power in educational organizations. Cresskill, NJ: Hampton.

Effah-Attoe Stella A. 2018. “Gender Mainstreamism in Nigeria’s Political Development. From Hindsight to Foresight." $79^{\text {th }}$ Inaugural Lecture, University of Calabar.

Fatunwa, Babs. 2004. History of Education in Nigeria. Ibadan: NPC Educational Pub. Ltd. Foucault, Michael. 1972. The archaeology of knowledge and the discourse language. New York: Partheon.

Foucault, Michael. 1977. Discipline and Punish. New York: Panthom.

Good, Carter. 1959. Dictionary of Education. New York: McGraw-Hill.

Idyorough, A. 2005. Gender: concepts and issues in Nigeria. Makurdi, Aboki Pub.

Ikime, Obauro. 1980. Government of Nigerian History. Ibadan Heinemann.

Ikpe, E. B. 2004. “The Historical Legacy of Gender Inequality in Nigeria.” in Paradox of Gender Equality in Nigerian politics, edited by S. O. Akinboye. Lagos: Concept Pub. Ltd.

Imam, Hauwa. 2012. "Educational Policy in Nigeria from the Colonial Era to the Post-Independence Period.” Italian Journal of Sociology of Education 1.

Jaggar, Alison. 1983. Feminist politics and human nature. Sussex: Rowman and Allanheld.

Mba, Nina, Emma. 1982. Nigeria women mobilized: Women political activity in southern Nigeria, 1900-1965. Berkeley: Institute of International Studies.

Mojekuru-Chikezie, Neamaka. 2012. African Women sentenced by tradition. Lagos: 
Nwokebi A.A. and Coy.

Nigeria. 2010. Nigeria at 50: A Compendium: The Official and Authoritative Book about Nigeria: $1^{\text {st }}$ October Publishing.

Nye, Joseph. 2004. Soft power: The mears to success in world politics. New York Public Affairs Press.

Ocitti, J. 1973. African indigenous Education: As practice by the Acholi of Uganda. Nairobi: East African Literature Bureau.

Odrowąż-Coates Anna. 2019. Socio-educational factors and the soft power of language: the deluge of English in Poland and Portugal. London: Lexington Books [Rowman \& Littlefield].

Odrowąż-Coates, Anna. 2015. "Gender Crisis in Poland, Catholic Ideology and the Media.” Sociology Mind 5: 27-34.

Odrowąż-Coates, Anna. 2018. "Soft power of language in social inclusion and exclusion and the unintended outcomes in Language.” Discourse and Society 6 (2):1530.

Pereira Charmaine. 2007. Gender in the Making of the Nigerian University System. Ibadan: Heinemann Educational Books.

Piscoe, Victor., Moeketsi. Letseka. 2013. “Fourcault's Discourse and power implications for structionist classroom management." Open Journal of Philosophy 3(1): 23-28.

Pocock John. Greville. Agard. 2018. "Theory in History Problems of Context and Narrative." in The Oxford Handbook of Political Science, edited by R. E. Goodin. Oxford: Oxford University Press.

Popkewitz, Thomas S. 1997. "Restricting of social and political theory in education four fowcault and a social epistemology of school practices." Educational theory 47: 287-313.

Silberschmidt, Margrethe. 1999. Women Forget that Men are their Masters. UPPSALA, Sweden. Nordiska Afrikainstitutet.

Talbari, Aziz. 1996. "Pedagogy, Power and discourse: Transformation of Islamic Education." Comparative Education Review 40: 66-82.

Weedon, Chris. 1997. Feminist practice and poststructuralist theory. Second Edition. Oxford: Blackwell.

Woolman, David. 2001. "Educational Reconstruction and Post-colonial Curriculum Development: A Comparative study of four African Countries.” International Education Journal 2(5): 27-46. 


\section{BIOGRAPHICAL NOTE}

Ekwutosi Essien Offiong, PhD is a Lecturer at the Department of History and International Studies, University of Calabar, Nigeria.

OPEN ACCESS: This article is distributed under the terms of the Creative Commons Attribution Non-commercial License (CC BY-NC 4.0) which permits any non-commercial use, and reproduction in any medium, provided the original author(s) and source are credited.

ARTICLE HISTORY: Received 2019-09-30 / Accepted 2019-11-30 
